\title{
Evidence for mantle metasomatism by hydrous silicic melts derived from subducted oceanic crust
}

\author{
[Letters to Nature]
}

Prouteau, Gaelle*†; Scaillet, Bruno¥; Pichavant, Michel¥; Maury, René*

UMR 6538, UBO, 6 avenue Le Gargeu, P.B. 809, 29285 Brest, France

¥ UMR G113, ISTO, 1a rue de la Férollerie, 45071 Orléans, France

† Present address: Laboratoire de Pétrologie, UPMC, 4 Place Jussieu, 75252, Paris, France.

\begin{abstract}
The low concentrations of niobium, tantalum and titanium observed in island-arc basalts are thought to result from modification of the sub-arc mantle by a metasomatic agent, deficient in these elements, that originates from within the subducted oceanic crust $\underline{1}$. Whether this agent is an hydrous fluid $\underline{2}$ or a silica-rich melt $\underline{3}$ has been discussed using mainly a trace-element approach $\underline{4}$ and related to variable thermal regimes of subduction zones $\underline{5}$. Melting of basalt in the absence of fluid both requires high temperatures and yields melt compositions unlike those found in most modern or Mesozoic island arcs 6,7. Thus, metasomatism by fluids has been thought to be the most common situation. Here, however, we show that the melting of basalt under both $\mathrm{H}_{2} \mathrm{O}$-added and low-temperature conditions can yield extremely alkali-rich silicic liquids, the alkali content of which increases with pressure. These liquids are deficient in titanium and in the elements niobium and tantalum and are virtually identical to glasses preserved in mantle xenoliths found in subduction zones $\underline{6}$ and to veins found in exhumed metamorphic terranes of fossil convergent zones $\underline{7}$. We also found that the interaction between such liquids and mantle olivine produces modal mineralogies that are identical to those observed in metasomatized Alpine-type peridotites $\underline{8}$. We therefore suggest that mantle metasomatism by slab-derived melt is a more common process than previously thought.
\end{abstract}

A mid-ocean ridge basalt from the Juan de Fuca ridge (Table 1) was reacted between 10 and 30 kbar with bulk $\mathrm{H}_{2} \mathrm{O}$ contents of 2 to $10 \mathrm{wt} \%$ (see ref. $\underline{9}$ for methods), that is, largely in excess of the $\mathrm{H}_{2} \mathrm{O}$ content of metamorphosed basalts, and at temperatures below $1,000^{\circ} \mathrm{C}$. Recent experimental work has shown that melting under these conditions (addition of $\mathrm{H}_{2} \mathrm{O}$, low temperatures) is required to account for the geochemical and physical characteristics of slab melts $\underline{9}$, and approaches the most likely pressure-temperature (P-T) conditions for slab melting $\left(750{ }^{\circ} \mathrm{C}, 30\right.$ kbar) as constrained from thermal modelling $\underline{10}$.

\begin{tabular}{|c|c|c|c|c|c|c|c|c|c|c|c|c|c|c|c|c|c|c|c|}
\hline & $P($ kbar $)$ & $T\left({ }^{\circ} \mathrm{C}\right)$ & $\mathrm{H}_{2} \mathrm{O}^{*}$ & $\mathrm{SiO}_{2}$ & $\mathrm{TiO}_{2}$ & $\mathrm{Al}_{2} \mathrm{O}_{3}$ & $\mathrm{FeO}+$ & $\mathrm{MgO}$ & $\mathrm{CaO}$ & $\mathrm{Na}_{2} \mathrm{O}$ & $\mathrm{K}_{2} \mathrm{O}$ & $\mathrm{Gl}$ & $\mathrm{Hbl}$ & Cpx & Gt & Tmt & $\| \mathrm{m}$ & Rut & Sph \\
\hline \multicolumn{20}{|c|}{ Experimental glasses from hydrous basalt melting } \\
\hline Starting $f$ & - & - & - & 49.9 & 2.3 & 13.7 & 12.7 & 6.8 & 10.6 & 2.5 & 0.3 & - & - & - & - & - & - & - & - \\
\hline & 10 & 841 & 9.9 & 69.8 & 0.2 & 18.7 & 0.9 & 0.5 & 5.8 & 3.4 & 0.6 & 41.1 & 26.0 & 21.7 & - & 8.6 & 2.6 & - & - \\
\hline 38 & 20 & 800 & 9.2 & 68.8 & 0.3 & 16.7 & 2.9 & 1.0 & 5.9 & 3.4 & 0.7 & 28.0 & 67.4 & - & - & - & 0.1 & - & 7.0 \\
\hline 39 & 20 & 900 & 10.2 & 65.4 & 0.4 & 20.9 & 1.7 & 0.2 & 7.0 & 3.7 & 0.6 & 36.2 & 39.1 & 20.9 & - & - & 4.0 & - & - \\
\hline 40 & 20 & 1,000 & 10.0 & 59.3 & 1.5 & 20.1 & 5.1 & 0.9 & 7.5 & 4.3 & 0.8 & 46.8 & 26.5 & 20.8 & - & 5.9 & - & - & - \\
\hline 41 & 30 & 900 & 6.4 & 70.9 & 0.3 & 16.1 & 0.5 & 0.1 & 1.4 & 9.3 & 1.5 & 23.9 & - & 42.9 & 31.8 & - & 0.4 & 0.9 & - \\
\hline 42 & 30 & 1,000 & 6.0 & 68.0 & 0.6 & 17.9 & 1.2 & 0.2 & 3.7 & 7.1 & 1.1 & 25.6 & - & 34.8 & 38.4 & - & - & 1.1 & - \\
\hline \multicolumn{20}{|c|}{ Felsic veins in mantle xenoliths or in metamorphic complexes from subduction zones } \\
\hline Val55/4 & - & - & - & 67.8 & 0.4 & 18.0 & 0.6 & 0.2 & 1.1 & 7.9 & 2.1 & - & - & - & - & - & - & - & - \\
\hline Val55/4 & - & - & - & 63.9 & 0.9 & 19.7 & 2.7 & 1.0 & 3.0 & 5.7 & 0.9 & - & - & - & - & - & - & - & - \\
\hline 41867A & - & - & - & 72.2 & 0.1 & 16.5 & 0.2 & 0.1 & 2.8 & 6.6 & 0.3 & - & - & - & - & - & - & - & - \\
\hline
\end{tabular}

Table 1 Experimental and natural glass/vein compositions and experimental phase proportions 
Representative glass (that is, quench melt) compositions are listed in Table 1. In a An-Ab-Or projection (Fig. 1), the glass compositions define a trend parallel to the albite-anorthite join. Glasses produced at both 10 and 20 kbar cluster in the tonalitic field, whereas those obtained at $30 \mathrm{kbar}$ fall within the trondhjemite field. The latter have $\mathrm{Na}_{2} \mathrm{O}$ contents in excess of 7 $w t \%$, increasing as temperature decreases, and are clearly peralkaline (molar $\mathrm{Al}_{2} \mathrm{O}_{3} / \mathrm{Na}_{2} \mathrm{O}+\mathrm{K}_{2} \mathrm{O}+\mathrm{CaO}<1$ ), whereas all the glasses produced at lower pressures tend to be either metaluminous or slightly peraluminous. The reason for the large compositional jump observed between 10-20 and $30 \mathrm{kbar}$ is that amphibole breaks down in this pressure range, and the modal abundances of garnet and clinopyroxene increase. The $\mathrm{Na}_{2} \mathrm{O}$ released by the amphibole breakdown is not fully balanced by the increase in the $\mathrm{Na}$ content of clinopyroxene (that is, the jadeite component) and thus, for a given $\mathrm{T}$ and bulk $\mathrm{H}_{2} \mathrm{O}$ content, the liquid becomes more sodic and less calcic as pressure increases beyond the amphibole stability field. Extensive garnet crystallization at $30 \mathrm{kbar}$ also lowers the $\mathrm{Al}_{2} \mathrm{O}_{3}$ content of the glasses relative to those at $20 \mathrm{kbar}$ (Table 1). In the $\mathrm{CaO}$ versus $\mathrm{Na}_{2} \mathrm{O}$ diagram (Fig. 2), all glasses so far produced in $\mathrm{H}_{2} \mathrm{O}$-added melting experiments on basalts up to 30 kbar 11-13 display a broad negative trend that completely overlaps that field of natural glasses or veins believed to be slab melts $\underline{6,7}$, in contrast to results from dehydration melting experiments $\underline{13-15}$ (Fig. 2b). A similar feature is observed for other elements such as $\mathrm{FeO}$ or $\mathrm{TiO}_{2}$. The melt $\mathrm{TiO}_{2}$ content (Table 1) agrees with existing rutile solubility models $\underline{16}$. At pressures lower than $10 \mathrm{kbar}$ the glasses are characterized by high $\mathrm{CaO}$ and relatively low $\mathrm{Na}_{2} \mathrm{O}$ contents, as well as a high $\mathrm{Al}_{2} \mathrm{O}_{3}$ content, due to the lack of both plagioclase and garnet in the residue 12,13 . In contrast, glasses obtained in the pressure range 20-30 kbar coexist with an eclogitic residue. Results obtained at 30 kbar match the composition of metasomatic veins the most closely, in particular the extreme $\mathrm{Na}_{2} \mathrm{O}$ enrichment. This suggests that these experimental conditionstemperatures below $900^{\circ} \mathrm{C}$ and bulk water content around 5-6 wt\%, thus requiring the presence of a fluid phase before melting-reproduce those of vein production. The origin of free water may lie in the dehydration of serpentinite beneath the oceanic crust of the subducted plate $\underline{17,18}$. The water thus produced is expected to dissolve in the melt, except at low melt fraction where there may be enough water to saturate the melt. Clearly, these conditions of slab melting better approach those predicted from thermal modelling 10 than do the conditions of the dehydration melting experiments. Therefore, we conclude that free water is needed at depth for slab melting to occur in present-day subduction zones. Experimental constraints on slab melts predict meltwater contents of at least $15 \mathrm{wt} \%$ (ref. $\underline{\text { ) }}$ ), whereas mass balance calculations on the run products obtained at 30 kbar yield meltwater contents between 24 and $30 \mathrm{wt} \%$. The unusual major-element composition of slab melts appears to be more characteristic of their origin than their trace element signature. In particular, melting in the garnet field of basalt underplated beneath the continental crust may yield silicic melts with trace element patterns similar to those of slab melts $\underline{19}$, but they will be granitic instead of trondhjemitic because less water is available in the lower crust and dehydration melting reactions are favoured. 


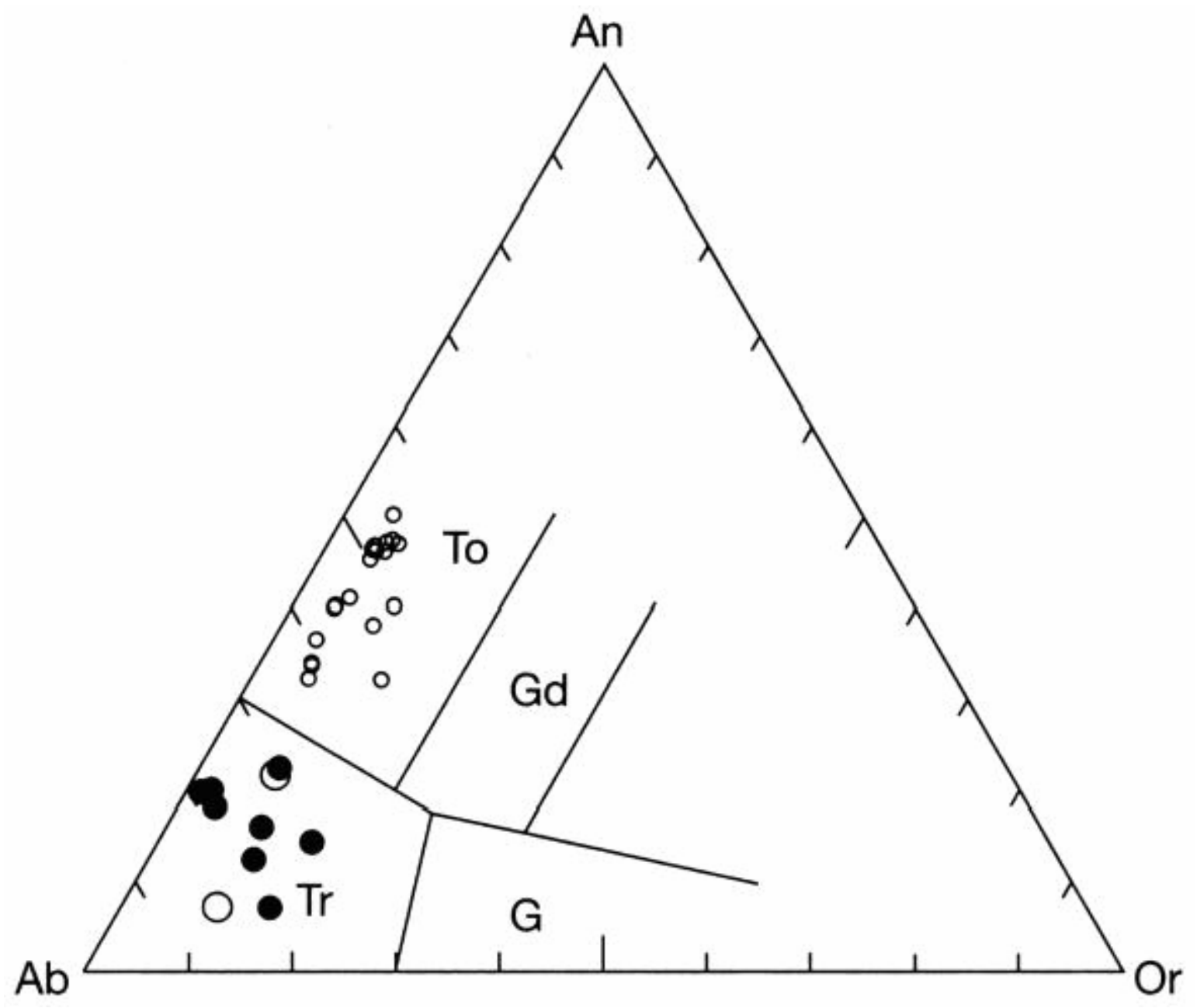

Figure 1 Normative (CIPW) compositions of natural slab melts (black circles) and of glasses obtained in melting experiments of basalts with added $\mathrm{H}_{2} \mathrm{O}$ (this study). Small white circles represent experiments done at or below 20 kbar and large white circles experiments at 30 kbar. An, anorbhite; Ab, albite; Or, orthoclase; To, tonalike, Tr, trondhjemite; Gd, granodiorite; G, granite. 


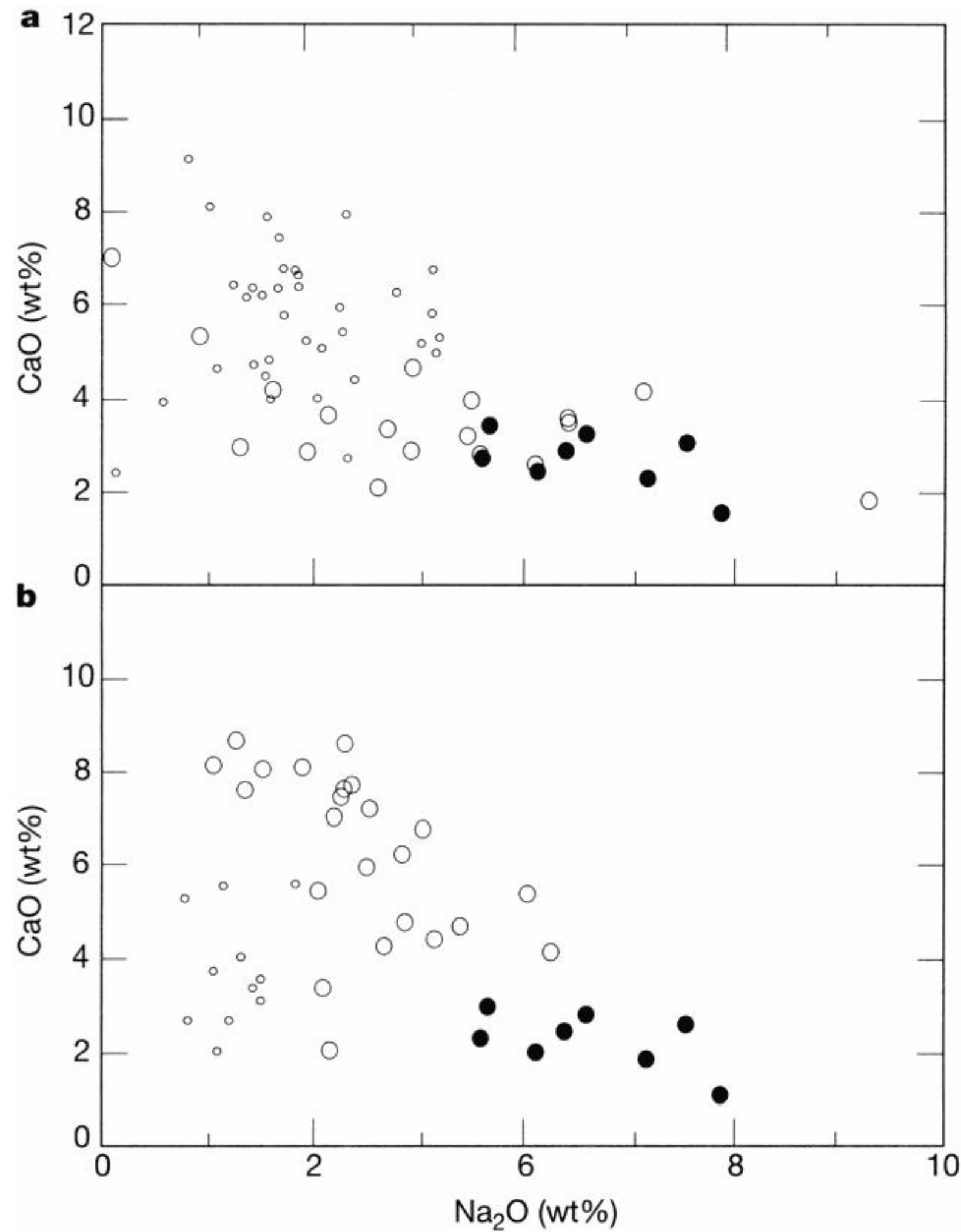

Figure $2 \mathrm{Na}_{2} \mathrm{O}$ versus $\mathrm{CaO}$ plot of natural slab melts $\underline{6,7}$ (black circles) and of glasses obtained in melting experiments (large white circles) using N-MORB type basalt protoliths. a, Glasses obtained in melting experiments with added $\mathrm{H}_{2} \mathrm{O}$ (this study and refs $\underline{11-13})$. b, Glasses obtained in dehydration melting experiments $\underline{13-15}$. Small white circles represent experiments done at or below $10 \mathrm{kbar}$ (in both a and b).

Interaction of such trondhjemitic melts with the overlying mantle wedge has been experimentally simulated at $15 \mathrm{kbar}$, as in previous similar works $20-22$, by mixing a synthetic equivalent of the trondhjemite melt obtained during melting of the basalt with a forsteritic olivine (Fo 90), the dominant mineral in peridotites (Table 2). Liquid and mineral 
compositions are listed in Table 2. At $1,000^{\circ} \mathrm{C}$, an orthopyroxene + liquid assemblage is produced. At $900{ }^{\circ} \mathrm{C}$, in addition to orthopyroxene, both an amphibole and phlogopite are reaction products of the interaction process. At both temperatures, olivine appears not to be stable, although residual crystals persist. Glass compositions are notably more magnesian and silica-poor than the starting trondhjemite, being dacitic instead of rhyolitic, yet their strongly alkali-rich character still persists or even increases (Table 2). An increase of the $\mathrm{Mg} /(\mathrm{Mg}+\mathrm{Fe})$ ratio of the liquid together with massive orthopyroxene crystallization are key features of geochemical models of slab melt/peridotite interaction $\underline{23}$ and reproduce diagnostic petrographic characteristics of slab-derived magmas 24. In addition, the compositions of amphibole and phlogopite, the two main minerals diagnostic of mantle metasomatism, are remarkably similar to those of natural amphibole and phlogopite found in some Alpine-type peridotite complexes believed to have been pervasively metasomatized by infiltrating slabderived melts $\underline{8}$. In particular, both minerals are characterized by high $\mathrm{Mg} /(\mathrm{Fe}+\mathrm{Mg})$ ratios and display strong enrichment in $\mathrm{Na}_{2} \mathrm{O}$. Given the large number of parameters involved in the interaction process (that is, compositions of peridotite and infiltrating melt, solid/melt ratio, pressure and temperature of the interaction) it is expected that metasomatic phases display a wide range of composition, as in previous laboratory studies 20-22 and natural occurrences 25. However, the sodic character of metasomatic minerals can be related to the sodic character of the metasomatizing agent, as evidenced by the trondhjemite veins of Kamchatka. Variable $\mathrm{Na}_{2} \mathrm{O}$ enrichment of metasomatic minerals would trace the more or less trondhjemitic character of the percolating melt which in turn depends on the conditions of its genesis, in particular pressure, as shown above. The similarity between the compositions of experimental and natural phases suggests that the interaction experiments reproduce the conditions of mantle metasomatism and in particular the chemistry of the metasomatic agent.

\begin{tabular}{|c|c|c|c|c|c|c|c|c|c|c|}
\hline & $\mathrm{SiO}_{2}$ & $\mathrm{TiO}_{2}$ & $\mathrm{Al}_{2} \mathrm{O}_{3}$ & $\mathrm{FeO}^{*}$ & $\mathrm{MgO}$ & $\mathrm{CaO}$ & $\mathrm{Na}_{2} \mathrm{O}$ & $\mathrm{K}_{2} \mathrm{O}$ & $\mathrm{NiO}$ & total \\
\hline \multicolumn{11}{|c|}{ Starting end members } \\
\hline Trondh & 71.2 & 0.5 & 16.9 & 0.5 & 0.1 & 1.5 & 7.8 & 1.5 & - & 100 \\
\hline Olivine & 40.8 & - & 0.1 & 10.8 & 47.8 & - & - & - & 0.3 & 99.7 \\
\hline \multicolumn{11}{|c|}{ Run product compositions } \\
\hline \multicolumn{11}{|c|}{$1,000^{\circ} \mathrm{C}, 7.8 \mathrm{wt} \% \mathrm{H}_{2} \mathrm{O}+$} \\
\hline Gl & 65.9 & 0.5 & 17.6 & 1.0 & 2.9 & 1.4 & 8.9 & 1.6 & $<0.1$ & 92.2 \\
\hline Opx & 58.3 & 0.1 & 0.8 & 3.8 & 35.3 & 0.9 & 0.1 & - & 0.2 & 99.5 \\
\hline \multicolumn{11}{|c|}{$900^{\circ} \mathrm{C}, 9.6 w t \% \mathrm{H}_{2} \mathrm{O}$} \\
\hline $\mathrm{Gl}$ & 64.2 & 0.5 & 18.8 & 1.1 & 1.5 & 1.0 & 11.4 & 1.5 & $<0.1$ & 89.6 \\
\hline Opx & 57.7 & 0.1 & 0.8 & 6.0 & 33.4 & 0.9 & 0.2 & - & 0.2 & 99.4 \\
\hline $\mathrm{Phl}$ & 41.9 & 1.6 & 14.2 & 2.9 & 24.4 & - & 2.7 & 6.3 & 0.2 & 94.4 \\
\hline Amph & 50.9 & 1.7 & 6.1 & 3.5 & 20.6 & 8.9 & 4.2 & 0.3 & 0.1 & 96.5 \\
\hline \multicolumn{11}{|c|}{ Hydrous phases in metasomatised peridotitef } \\
\hline $\mathrm{Phl}$ & 41.9 & 0.7 & 14.3 & 2.8 & 25.3 & 0.0 & 1.6 & 6.5 & - & 94.6 \\
\hline Amph & 49.9 & 0.4 & 7.5 & 3.4 & 20.2 & 10.2 & 3.8 & 0.6 & - & 98.3 \\
\hline
\end{tabular}

Table 2 Glass and mineral compositions from trondhjemite-Fo90 olivine interactions at 15 kbar

The above experimental evidence bears direct constraints on metasomatic processes in arc settings. The low-temperature, fluid-present melting conditions above suggest that slab melting can occur in presently subducting plates, as previously suggested on geochemical grounds $\underline{5}$. Although slab melting was originally supposed to have occurred mostly during the Archaean $\underline{26}$ or only when young and hot plate subducts in modern settings $\underline{5}$, the increasing number of occurrences of magmas with slab melt signatures worldwide $\underline{27}$ suggests that conditions for slab melting are realized more often than currently believed. The slab melt contribution as a metasomatizing agent of the sub-arc mantle may thus be important. Mass balance calculations indicate that $15 \mathrm{~g}$ of trondhjemite yields $1 \mathrm{~g}$ of phlogopite upon reaction with peridotite, whereas $180 \mathrm{~g}$ of hydrous fluid are needed to precipitate an equivalent mass 
of phlogopite during a peridotite-fluid interaction $\underline{28}$. Thus, as far as metasomatic mineral production is concerned, slab-derived melts are about ten times more efficient than hydrous fluids. Consequently, the geochemical imprint of slab melts can be important in modern arc settings even if slab melting is probably less common than slab dehydration $\underline{29}$. In particular, calculated trace-element concentrations in slab melts in equilibrium with an eclogitic residue (garnet+clinopyroxene+/-rutile) are enriched in light-rare-earth and large-ion-lithophile elements and depleted in high-field-strength elements $(\mathrm{La} / \mathrm{Nb}=7 ; \mathrm{Ba} / \mathrm{Nb}=186$; ref. 22) and will impart their geochemical signature to magmas generated in the mantle wedge $\underline{24}$.

The overall slab contribution to the source of arc magmas is estimated not to exceed $3 \%$ on the basis of oxygen isotope systematics of oceanic arc lavas $\underline{30}$. The reason why slab melts (adakites) are found in volumetrically minor amounts relative to regular calc-alkaline arc magmas may be either physical or chemical. Silica-rich liquids can equilibrate with mantle minerals provided they are alkali-rich $\underline{31}$. This alkali effect is most pronounced at pressures below $20 \mathrm{kbar}$, however. At $30 \mathrm{kbar}$, liquids in equilibrium with mantle peridotite are not alkali-rich. The alkali content of experimental slab melts increases with pressure, and comparison with their natural equivalents has shown that slab melting is likely to occur at 30 kbar or more. Thus, besides the physical aspects of magma transport and percolation, any alkali-rich slab melt produced at or beyond $30 \mathrm{kbar}$, as in our experiments, will be in strong chemical disequilibrium with the overlying mantle wedge. Extensive interaction between these melts and peridotite is expected to occur and the alkali-rich, silica-rich melts will have little opportunity to reach shallower levels unchanged. On this basis, preservation or eruption of genuine slab melts can be anticipated to be difficult, accounting for their relative rarity in most arcs. The chemical differences observed between experimentally produced slab-melts and those erupted or preserved as melt inclusions $\underline{32}$ must in fact reflect various extents of interaction of the latter with mantle material during upward migration.

1. Hofmann, A. W. Chemical differentiation of the Earth: the relationships between mantle, continental crust, and oceanic crust. Earth Planet. Sci. Lett. 90, 297-314 (1988).

2. Eiler, J. M., McInnes, B., Valley, J. W., Graham, C. M. \& Stolper, E. M. Oxygen isotope evidence for slab-derived fluids in the sub-arc mantle. Nature 393, 777-781 (1998).

3. Nicholls, I. A. \& Ringwood, A. E. Effect of water on olivine stability in tholeiites and production of silica saturated magmas in island are environment. J. Geol. 81, 285-300 (1973).

4. Hawkesworth, C. J., Turner, S.P., McDermott, F., Peate, D. W. \& van Calsteren, P. UThisotopes in arc magmas: implications for element transfer from the subducted crust. Science 276, 551-555 (1997).

5. Defant, M. J. \& Drummond, M. S. Derivation of some modern arc magmas by melting of young subducted lithosphere. Nature 347, 662-665 (1990).

6. Kepezhinskas, P. K., Defant, M. J. \& Drummond, M. S. Na metasomatism in the island-arc mantle by slab melt-peridotite interaction: evidence from mantle xenoliths in the north Kamchatka arc. J. Petrol. 36, 1505-1527 (1995).

7. Sorensen, S. S. \& Grossman, J. N. Enrichment of trace elements in garnet amphibolites from a paleosubduction zone: Catalina Schist, southern California. Geochim. Cosmochim. Acta 53, 3155-3177 (1989). 
8. Zanetti, A., Mazzucchelli, Rivalenti, G. \& Vannucci, R. The Finero phlogopite-peridotite massif: an example of subduction-related metasomatism. Contrib. Mineral. Petrol. 134, 107122 (1999). Full Text Bibliographic Links

9. Prouteau, G., Scaillet, B., Pichavant, M. \& Maury, R. C. Fluid-present melting of ocean crust in subduction zones. Geology 27, 1111-1114 (1999). Bibliographic Links

10. Peacock, S. M., Rushmer, T. \& Thompson, A. B. Partial melting of subducting oceanic crust. Earth Planet. Sci. Lett. 121, 227-244 (1994).

11. Whinter, K. T. \& Newton, R. C. Experimental melting of hydrous low-K tholeiite: evidence on the origin of Archean cratons. Bull. Geol. Soc. Denmark 39, 213-228 (1991).

12. Spulber, S. D. \& Rutherford, M. J. The origin of rhyolite and plagiogranite in oceanic crust: an experimental study. J. Petrol. 24, 1-25 (1983).

13. Beard, J. S. \& Lofgren, G. E. Dehydration melting and water-saturated melting of basaltic and andesitic greenstones and amphibolites at 1, 3, and 6.9 kb. J. Petrol. 32, 365-401 (1991).

14. Rapp, R. P. \& Watson, E. B. Dehydration melting of metabasalt at 8-32 kbar: implications for continental growth and crust-mantle recycling. J. Petrol. 36, 891-931 (1995).

15. Sen, C. \& Dunn, T. Dehydration melting of a basaltic composition amphibolite at 1.5 and 2.0 GPa: implications for the origin of adakites. Contrib. Mineral. Petrol. 117, 394-409 (1994).

16. Ryerson, E. J. \& Watson, E. B. Rutile saturation in magmas: implications for Ti-Nb-Ta depletion in island-arc basalts. Earth Planet. Sci. Lett. 86, 225-239 (1987).

17. Ulmer, P. \& Trommsdorff, V. Serpentinite stability to mantle depths and subductionrelated magmatism. Science 268, 858-861 (1995).

18. Schmidt, M. \& Poli, S. Experimentally based water budget for dehydrating slabs and consequences for are magma generation. Earth Planet. Sci. Lett. 163, 361-379 (1998).

19. Atherton, M. P. \& Petford, N. Generation of sodium-rich magmas from newly underplated basaltic crust. Nature 362, 144-146 (1993).

20. Carroll, M. J. \& Wyllie, P. J. Experimental phase relations in the system peridotitetonalite- $\mathrm{H}_{2} \mathrm{O}$ at 15 kbar: implications for assimilation and differentiation processes at the crust-mantle boundary. J. Petrol. 30, 1351-1382 (1989).

21. Sen, C. \& Dunn, T. Experimental modal metasomatism of a spinel lherzolite and the production of amphibole-bearing peridotite. Contrib. Petrol. Mineral. 119, 422-432 (1994).

22. Rapp, R. P., Shimizu, N., Norman, M. D. \& Applegate, G. S. Reaction between slabderived melts and peridotite in the mantle wedge: experimental constraints at $3.8 \mathrm{GPa}$. Chem. Geol. 160, 335-356 (1999). 
23. Kelemen, P., Shimizu, N. \& Dunn, T. Relative depletion of niobium in some arc magmas and the continental crust: partitioning of $\mathrm{K}, \mathrm{Nb}$, $\mathrm{La}$, and Ce during melt/rock reaction in the upper mantle. Earth Planet. Sci. Lett. 120, 111-134 (1993).

24. Yogodinzski, G. M., Volynets, O. N., Koloskov, A. V. \& Seliverstov, N. I. Magnesian andesites and the subduction component in a strongly calcalkaline series at Piip volcano, far western Aleutian. J. Petrol. 34, 163-204 (1994).

25. Ionov, D. A. \& Hofmann, A. W. Nb-Ta-rich mantle amphiboles and micas: implications for subduction-related metasomatic trace element fractionations. Chem. Geol. 131, 341-356 (1995).

26. Martin, H. Effect of steeper Archean geothermal gradient on geochemistry of subduction zone magmas. Geology 14, 753-756 (1986).

27. Drummond, M. S., Defant, M. J. \& Kepezhinskas, P K. Petrogenesis of slab derivedtonalite-dacite adakite magmas. Trans. R. Soc. Edinburgh 87, 205-215 (1996).

28. Schneider, M. E. \& Eggler, D. H. Fluids in equilibrium with peridotite minerals: implications for mantle metasomatism. Geochim. Cosmochim. Acta 50, 711-724 (1986).

29. Tatsumi, Y. Migration of fluid phases and genesis of basalt magmas in subduction zones. J. Geophys. Res 94, 4697-4707 (1989).

30. Eiler, J. M. et al. Oxygen isotopes geochemistry of oceanic-arc lavas. J. Petrol. 41, 229256 (2000).

31. Hirschman, M. M, Baker, M. B. \& Stolper, E. M. The effect of alkalis on the silica content of mantle-derived melts. Geochim. Cosmochim. Acta 62, 883-902 (1998).

32. Schiano, P. et al. Hydrous, silica-rich melts in the sub-arc mantle and their relationship with erupted arc-lavas. Nature 377, 595-600 (1995). 